\title{
ARTÍCULOS
}

\section{Seasonal diet of Lama guanicoe (Camelidae: Artiodactyla) in a heterogeneous landscape of South Patagonia}

\author{
Dieta estacional de Lama guanicoe (Camelidae: Artiodactyla) en un paisaje \\ heterogéneo de Patagonia Sur
}

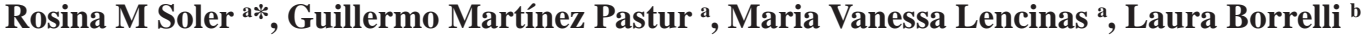

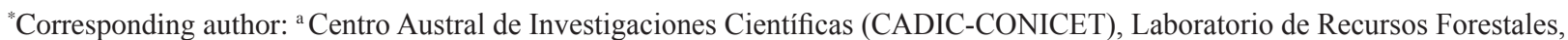 \\ Houssay 200, (9410) Ushuaia, Tierra del Fuego, Argentina, phone: +54-2901-422310 (Int. 111), rosinas@cadic-conicet.gob.ar \\ ${ }^{\mathrm{b}}$ Instituto Nacional de Tecnología Agropecuaria (INTA), Bariloche, Rio Negro, Argentina.
}

\begin{abstract}
SUMMARY
Large diversity of habitat types, plant species assemblages, and silvopastoral activities in Nothofagus spp. forests condition the food availability for native herbivores. This work evaluates the seasonal diet of Lama guanicoe linked to plant life forms and habitat types in sub-Antarctic forests. The study evaluated vegetation availability and habitat types by floristic surveys $(\mathrm{n}=206)$ in Tierra del Fuego, and seasonal diet of L. guanicoe by a micro-histological analysis of feces ( $\mathrm{n}=4$ in four areas, during four season). Open lands showed the highest plant richness, while lowest values corresponded to primary Nothofagus pumilio forests. Nothofagus pumilio (21.6 \%), Carex spp. (17.2 \%), Misodendrum spp. (10.6\%) and Deschampsia spp. (8.6\%) were the most frequent items found in feces. Significant differences were seasonally found in diet composition and trophic niche breadth: grasses were all consumed along the year, while tree browsing decreased and the proportion of shrubs increased in winter. This study highlights the widespread use of different habitats by guanaco, including harvested forests. In summer and spring Nothofagus spp. forests were the main source of food for guanacos, depending more on open lands during winter. The knowledge of plant-native herbivores interactions in productive landscapes could improve the management plans towards an ecologically sustainable strategy.
\end{abstract}

Key words: grasses, guanaco, landscape, plant assemblage, tree seedlings.

\section{RESUMEN}

La heterogeneidad de hábitat, distintos ensambles de especies vegetales y las actividades productivas en bosques del género Nothofagus condicionan la disponibilidad de alimento para los herbívoros nativos. Este trabajo evalúa la dieta estacional de Lama guanicoe vinculada a la vegetación, los tipos de hábitat y el manejo forestal en Tierra del Fuego. Se realizaron censos de vegetación $(\mathrm{n}=206)$ y se estudió la dieta de L. guanicoe mediante recolección de heces y análisis micro-histológico ( $\mathrm{n}=4$ en cuatro áreas, durante las cuatro estaciones). Las áreas abiertas tuvieron la mayor riqueza específica, mientras que los valores más bajos correspondieron a bosques primarios de Nothofagus pumilio. La dieta de L. guanicoe incluyó 25 especies y 13 géneros de plantas y un musgo (Sphagnum spp.). Nothofagus pumilio (21,6 \%), Carex spp. (17,2 \%), Misodendrum spp. (10,6 \%) y Deschampsia spp. (8,6 \%) fueron los ítems más frecuentes en la dieta. Se registraron diferencias estacionales tanto en la composición como en la amplitud del nicho trófico: el consumo de pastos fue continuo durante todo el año, el ramoneo de árboles disminuyó en invierno y aumentó el consumo de arbustos perennes. Este estudio confirma que el guanaco utiliza una amplia variedad de ambientes, incluyendo bosques cosechados. En verano y primavera los bosques de Nothofagus spp. fueron los principales sitios de alimentación para los guanacos, dependiendo más del alimento en áreas abiertas durante el invierno. El conocimiento de las interacciones planta-herbívoros nativos en paisajes con manejo agro-forestal podría mejorar los planes de manejo hacia un uso ecológicamente sustentable.

Palabras clave: ensamble de plantas, guanaco, pastos, paisaje, plántulas leñosas.

\section{INTRODUCTION}

The multiple-use character of forests means that many different and sometimes conflicting goals exist (e.g. timber production, silvopastoral, tourism and recreation, conservation of wildlife habitat) regarding their management (Luque et al. 2011). In South Patagonia, Nothofagus spp. forests are considered one of the world's largest and most pristine temperate forests (Mittermeier et al. 2003). On the other hand, forest harvesting takes an important role in the socio-economic development of southern Patagonia, mainly in Tierra del Fuego.

In Tierra del Fuego (Argentina), landscapes are forested mosaics where timber-quality forests of Nothofagus pumi- 
lio (Poepp. et Endl.) Krasser 1896 (lenga) are interspersed along with other habitat types (Lencinas et al. 2008) such as open lands (grasslands, peatlands) and associated low timber-quality forests of $N$. antcarctica (Forster f.) Oersted 1871 (ñire). Each habitat type presents a characteristic assemblage of plant species and vegetation formations. At the same time, harvesting and silvopastoral practices of Nothofagus spp. forests modify the original composition of understory plants compared to primary unmanaged forests (Martínez Pastur et al. 2002). That includes tree seedlings and saplings, which are key components to ensure the maintenance of the tree layer. This landscape heterogeneity and different plant assemblages offer a variety of food resources for native ungulates (Raedeke 1978, Pulido et al. 2000, Cavieres and Fajardo 2005).

Populations of native large herbivores are affected by environmental changes, in terms of spatial and temporal heterogeneity in food availability (Raedeke 1978), as well as the presence of competitive livestock with which they share the habitat in productive systems (Soler et al. 2012). In this way, native herbivores perceive and respond to variation in plant quality and quantity across multiple spatial scales (Edenius et al. 2002).

Historically, the sub-Antarctic forests have been inhabited by guanacos (Lama guanicoe, Müller 1776), the only one large native herbivore (Raedeke 1978, Muñoz 2008). It is a generalist species and the most abundant free-ranging ungulate throughout Patagonia, but it is commonly sharing habitats with domestic herbivores (i.e. cattle and sheep). Despite their preference for open habitats (Puig et al. 1997), guanaco does move into the forest, consuming not only $N$. pumilio seedlings and saplings (Pulido et al. 2000) but also other plants growing there. Although this native herbivore has coexisted with Nothofagus spp. forests for centuries (Raedeke 1978, Pulido et al. 2000, Muñoz 2008), several authors affirm that regeneration of these forests can be inhibited by guanaco browsing (Pulido et al. 2000, Cavieres and Fajardo 2005). It has been also reported that livestock browsing creates serious problems for natural regeneration growth of $N$. pumilio. However, we consider there has been no quantitative evaluation of the impact of ungulate browsing on Nothofagus species. Even less information exists about the role of different functional groups of plants in the diet of native ungulates, under different scenarios of Nothofagus spp. forest management and livestock.

In this study we investigate the seasonal diet composition of guanacos, linked to the available vegetation during summer season in different habitat types of Tierra del Fuego (Argentina). To achieve this goal, we addressed the following questions: i) what is the assemblage of plant species and different vegetation community types across the landscape?, ii) is the herbivores' diet determined by the availability of life-form groups of plants in space and time?, iii) how is the relationship between diet and the use of different habitat types in this landscape?

\section{METHODS}

Site description. The study was conducted in an area of $100 \mathrm{~km}^{2}$, "Los Cerros" ranch (figure 1) in the central zone

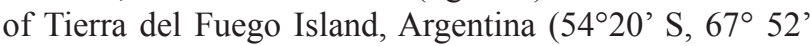
W). The climate is characterized by short, cool summers (mean: $14^{\circ} \mathrm{C}$ ), and long snowy and frozen winters (mean: $-7^{\circ} \mathrm{C}$ ). Precipitation is near $700 \mathrm{~mm}$ per year. The growing season of vegetation extends for about five months (November to March), but tree leaves fully expanded during January and February, with signs of early senescence during March (Moore 1983).

We classified this area through high definition satellite images (Quickbird images, March 2008) into a GIS, and checked in the field during the vegetation surveys. Open lands occupied $28.7 \%$ of the area (grasslands $24.9 \%$ and peatlands $3.8 \%$ ), while Nothofagus spp. forests occupied $71.3 \%$ ( N. antarctica forests $19.4 \%$, primary N. pumilio forests $42.7 \%$ and harvested $N$. pumilio forests $9.2 \%$ ). The Nothofagus spp. managed stands selected for this study were harvested (1-5 years) using a variable retention method (Martínez Pastur et al. 2009), which included non-harvested aggregated retention areas (30\% of the stand) and harvested areas with dispersed retention (70\% of the stand).

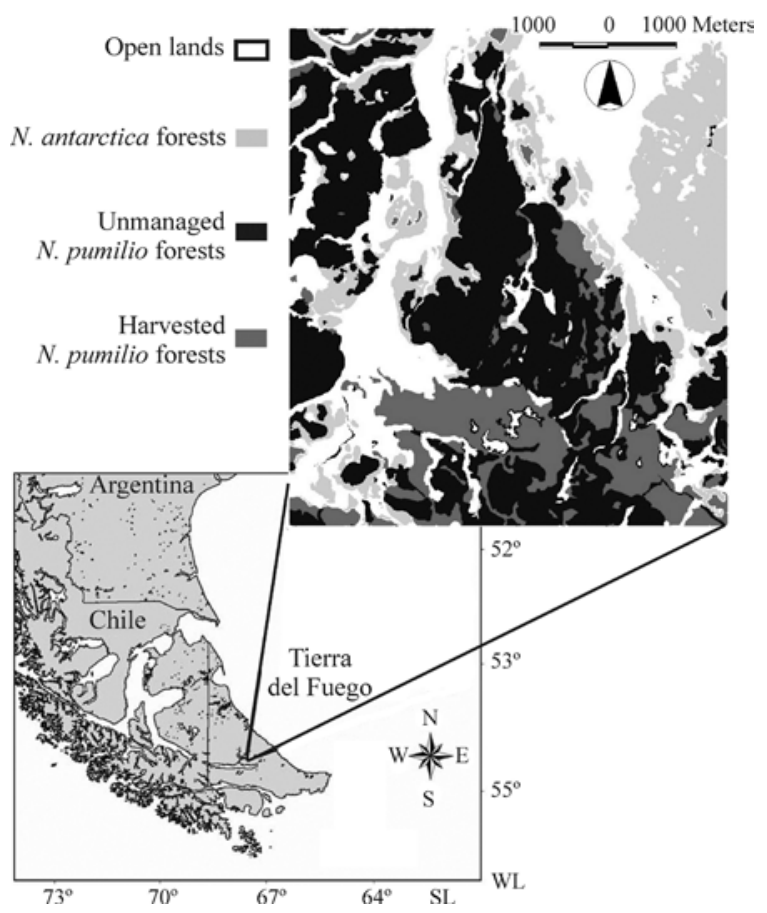

Figure 1. Study area in central Tierra del Fuego showing different habitat types: white $=$ open land, pale gray $=N$. antarctica forest, black = primary unmanaged $N$. pumilio forest, dark gray $=$ harvested $N$. pumilio forest.

Área de estudio en el centro de Tierra del Fuego, donde pueden observarse los distintos ambientes estudiados: blanco $=$ áreas abiertas, gris claro = bosque de $N$. antarctica, negro $=$ bosque $\sin$ manejo de $N$. pumilio, gris oscuro = bosque cosechado de $N$. pumilio . 
Montes et al. (2000) estimated a density of 2 individuals $\mathrm{km}^{-2}$ for guanacos populations in this area. During the pre-breeding season (October-November) guanacos are concentrated mainly in the forest-steppe area, but in winter they seek shelter and tend to spend more time in the coastal regions associated with forest (Montes et al. 2000). On the other hand, livestock density is about 12 individuals $\mathrm{km}^{-2}$ (cattle) in the study area, corresponding mainly to Hereford breed. The traditional grazing management is based on winter and summer extensive grazing ground (400-1,000 ha approximately), where each grazing ground includes mixed habitat types $(N$. antarctica forests, grasslands, and peatlands) (Ormaechea et al. 2009). Livestock movements depend on ranching management decisions, but usually are free-ranging, feeding along grasslands in the steppes and occasional browsing of forest plant species (Somlo et al. 1997).

Vegetation analyses. During summer season (2007 and 2008), floristic surveys were conducted in the study area. Based on existent GIS data and the different management schemes in the study area, four habitat types were defined as: 1) open lands (i.e. peatlands and grasslands) (OL): 2) Nothofagus antarctica forest (Ñ); 3) unmanaged N. pumilio forest (PF), which has not been previously logged; 4) harvested $N$. pumilio forest (HF).

A total of 206 vegetation surveys were conducted, according to the heterogeneous distribution at the landscape and resulting in unequal number of replicates $(\mathrm{OL}=30$; $\tilde{\mathrm{N}}=70 ; \mathrm{HF}=80 ; \mathrm{PF}=26$ ). Surveys were randomly distributed in the habitats, and the Braun Blanquet sampling method was applied following Pauchard et al. (2000) for estimations of vegetation availability in circular plots of $30 \mathrm{~m}$ radius $\left(2,827 \mathrm{~m}^{2}\right)$. Vascular plants (Dicotyledonae, Monocotyledonae, and Pteridophytae) were taxonomically classified at species level following Moore (1983). Then, species were grouped according to their life form as: tree seedlings and saplings (trees less than $1 \mathrm{~m}$ height), shrubs, erect herbs, prostrate herbs, caespitose grasses, and rhizomatous grasses. Species richness was calculated as the total number of species per habitat type, and relative frequency of each species was calculated as a proportion of one species within the plot and divided by the total proportion of the vegetation cover in each plot.

Fecal collection and micro-histological analyses. Feces samples were collected during spring (October 2007), summer (January 2008), autumn (April 2008) and winter (August 2008). We identified four sampling sectors within the ranch as current use latrines, independently of the vegetation sampling points because the latrines are located mainly in Nothofagus spp. forests, and rarely found guanacos latrines in open lands (e.g., peatlands or grasslands) in this region. Also considering that guanacos walk long distances at day looking for food or water, they could feed in several sites far from latrines. In each sector (approximately $1 \mathrm{ha}$ ), five fresh dung piles were collected and pooled, resulting in one sample by sector by season ( $\mathrm{n}=16$ samples). Botanical composition of feces was determined by identifying plant epidermal and no epidermal fragments according to the micro-histological analysis method (Sepúlveda et al. 2004). Pool samples were oven-dried at $60^{\circ} \mathrm{C}$ for $48 \mathrm{~h}$, ground to $<1 \mathrm{~mm}$ in a Cole-Parmer analytical mill (USA), depigmented with alcohol $70^{\circ}$, colored with safranin and mounted on five microscope slides of $24 \times 40 \mathrm{~mm}$ in glycerin-jelly. Twenty random field observations per slide were performed; thus, a total of 100 fields per pool sample were obtained. Quantification of the species components was achieved through the frequencies of each species. Plant epidermal fragments were identified using $100 \times$ magnifications, based on their morphological characteristics at species or genus level, and classified in the different life forms, also including bryophyte (B) or hemiparasitic shrub (HS) categories. N. pumilio and N. antarctica were differentiated through the stoma distribution patterns in the epidermis, swelling of cuticle and trichomes (Ragonese 1981).

Data analyses. All data were tested for normal distribution using the Shapiro-Wilks test. The plant life forms groups were also tested for homogeneity of variance with Levene's test $(P<0.05)$. One-way factor ANOVAs were performed to evaluate differences in: i) the vegetation cover classified by life forms in different habitat types, ii) the proportion of plant life forms constituting the seasonal diet. A post-hoc Tukey's test was used for all mean comparisons $(P<0.05)$. No corrections were made to consider the differential digestibility of plant species (Bonino and Pelliza Sbriller 1991). In addition, differences in the frequency of plant species in the diets across seasons were analyzed using a Chi square test.

Diet was characterized by three indices. The trophic niche breadth was determined by Levins's standardized index $\left(B_{s t}\right.$, Krebs 1989), which ranges from 0 (preference for only a few resources) to 1 (all available resources used equally):

$B_{s t}=\frac{(B-1)}{(B+1)}$

In this formula, $B$ is the Levin's trophic niche breadth:

$B=\frac{1}{\Sigma \mathrm{p} i^{2}}$

where pi is the proportion of a single food item in relation to the overall consumption. Diet selection was analyzed considering vegetation cover in the field during summer as an estimation of food availability, according Ivlev's selectivity index (S, Krebs 1989):

$S=\frac{\mathrm{ri}-\mathrm{pi}}{\mathrm{ri}+\mathrm{p} i}$ 
where ri is the relative abundance of plant group $i$ in the guanacos feces, and pi is the cover of that group in the field. $S$ varies between -1 (strong avoidance) and 1 (strong selection); while values from -0.09 to 0.09 mean indifference (Krebs 1989, Borgina et al. 2010). Finally, we performed an index to graph the relationship between plant species found in guanaco's feces and vegetation census (plant cover at the landscape). Seasonal differences in the niche breadth were tested with one-way ANOVA.

\section{RESULTS}

Vegetation composition. A total of 113 species of vascular plants were recorded during the vegetation census, where 71 species were dicots (Appendix 1), 39 monocots (Appendix 2) and three ferns (Appendix 3). The most abundant species at the landscape level were: Galium aparine (17.6 \%), Poa pratensis (11.9 \%), N. pumilio (9.7 \%), Cotula scariosa (8.5\%), Osmorhiza depauperata (7.1\%), Empetrum rubrum (4.0\%), Carex curta (3.3\%), Taraxacum officinale (3.3\%) and N. antarctica (2.0\%). Despite this, 58 species presented less than $0.1 \%$ cover at the landscape level (40 dicots, 17 monocots and one fern). Richness was higher in open lands (83 species) than in woodland sites $(\mathrm{HF}=63, \tilde{\mathrm{N}}=57$ and $\mathrm{PF}=26$ species). The most abundant species found in each habitat type were: E. rubrum and C. curta in open lands ( $14.1 \%$ and $11.7 \%$, respectively); G. aparine and O. depauperata in harvested $N$. pumilio forests ( $16.1 \%$ and $13.0 \%$, respectively), C. scariosa and P. pratensis in Nothofagus antarctica forests $(22.1 \%$ and $17.5 \%$, respectively); and G. aparine and $N$. pumilio seedlings in unmanaged $N$. pumilio forests (33.8 \% and 21.2 \%, respectively) (Appendices 1 to 3).

Significant differences were found for the cover of plants functional groups for each habitat type (table 1). Cover of shrubs, caespitose and rhizomatous grasses were higher in open lands, while tree seedlings and saplings were higher in unmanaged N. pumilio forests. The groups of herbs were higher in forested areas (PF, HF and $\tilde{N})$.

Seasonal diet analyses. Guanaco's feces samples contained 37 taxa of vascular plants and 1 moss (Sphagnum). A total of 25 plants were identified at species level and 13 at genus level (table 2). The species and genera recognized in the feces potentially included 58 of the 113 species identified during the vegetation census. Nothofagus pumilio (21.6 \%), Carex spp. (17.2 \%), Misodendrum spp. (10.6 $\%)$ and Deschampsia spp. (8.6 \%) were the most frequent taxa found in feces all year round (table 2). Rhizomatous grasses and tree seedlings and saplings were the main components of the feces, with $28.1 \%$ and $23.9 \%$ mean annual percentages, while prostrate herbs was the least frequent group with $6.7 \%$ mean annual percentage (e.g. Arjona spp., C. scariosa, Gunnera magellanica, Nanodea mucosa, Ranunculus and Vicia magellanica).

Niche breadth $(F=3.61, \mathrm{df}=3, P=0.045)$ was significantly higher in winter (0.49) and lower in spring (0.31), with intermediate values for autumn (0.43) and summer (0.41). The consumption of some plant species showed seasonal differences: a) Rubus geoides $\left(\chi^{2}=15.02, \mathrm{df}=\right.$ $3, P=0.001)$ was exclusively consumed during spring $(5.0 \%)$; b) Geum magellanicum $\left(\chi^{2}=32.20, \mathrm{df}=3\right.$, $P<0.001)$ and $N$. antarctica $\left(\chi^{2}=8.62, \mathrm{df}=3, P=0.03\right)$ were significantly higher in summer (10.7 and $5.3 \%$, respectively); c) Plantago barbata $\left(\chi^{2}=30.40, \mathrm{df}=3\right.$, $P<0.001)$ and Berberis buxifolia $\left(\chi^{2}=3.96, \mathrm{df}=3, P=\right.$ $0.050)$ were significantly superior during autumn (10.3 and $5.0 \%)$; and d) Juncus scheuzerioides $\left(\chi^{2}=16.62, \mathrm{df}=3\right.$, $P=0.001)$ was significantly more consumed during winter $(7.5 \%)$. Finally, N. pumilio was consumed all around the year $(23.5 \%-31.7 \%)$, but decreased during winter $\left(\chi^{2}=28.25, \mathrm{df}=3, P<0.001\right)$ when this item represents less than $1 \%$.

Table 1. One-way ANOVA for coverage (\%) of tree seedlings and saplings (T), shrubs (S), erect herbs (EH), prostrate herbs (PH), caespitose grasses $(\mathrm{CG})$, rhizomatous grasses $(\mathrm{RG})$, at different habitat types: open lands $(\mathrm{OL}), N$. antarctica forests (Ñ), primary unmanaged $N$. pumilio forests $(\mathrm{PF})$, harvested $N$. pumilio forests $(\mathrm{HF})$.

ANDEVA de un factor para evaluar la cobertura (\%) de plántulas de Nothofagus spp. (T), arbustos (S), hierbas erectas (EH), hierbas postradas $(\mathrm{PH})$, pastos cespitosos $(\mathrm{CG})$ y pastos rizomatosos $(\mathrm{RG})$, en diferentes tipos de hábitat: áreas abiertas (OL), bosques de N. antarctica (N), bosques primarios de $N$. pumilio (PF) y bosques cosechados de $N$. pumilio (HF).

\begin{tabular}{|c|c|c|c|c|c|c|}
\hline \multirow{2}{*}{ Habitat } & \multicolumn{6}{|c|}{ Life forms } \\
\hline & $\mathrm{T}$ & $S$ & $\mathrm{EH}$ & $\mathrm{PH}$ & $\mathrm{CG}$ & $\mathrm{RG}$ \\
\hline OL & $5.84^{\mathrm{ab}}$ & $20.56^{\mathrm{b}}$ & $10.36^{\mathrm{a}}$ & $8.36^{\mathrm{a}}$ & $18.13^{c}$ & $36.73^{c}$ \\
\hline$\tilde{\mathrm{N}}$ & $1.48^{\mathrm{a}}$ & $1.48^{\mathrm{a}}$ & $21.26^{\mathrm{bc}}$ & $41.68^{\mathrm{b}}$ & $11.73^{\mathrm{b}}$ & $22.34^{b}$ \\
\hline $\mathrm{PF}$ & $21.33^{c}$ & $0.04^{\mathrm{a}}$ & $17.13^{\mathrm{ab}}$ & $46.80^{\mathrm{b}}$ & $3.22^{\mathrm{a}}$ & $10.83^{\mathrm{a}}$ \\
\hline $\mathrm{HF}$ & $6.86^{\mathrm{b}}$ & $0.51^{\mathrm{a}}$ & $26.35^{c}$ & $47.43^{b}$ & $4.85^{\mathrm{a}}$ & $14.62^{\mathrm{a}}$ \\
\hline $\mathrm{F}(P)$ & $\begin{array}{c}41.75 \\
(<0.01)\end{array}$ & $\begin{array}{c}31.95 \\
(<0.01)\end{array}$ & $\begin{array}{c}11.03 \\
(<0.01)\end{array}$ & $\begin{array}{c}44.68 \\
(<0.01)\end{array}$ & $\begin{array}{c}19.49 \\
(<0.01)\end{array}$ & $\begin{array}{c}19.23 \\
(<0.01)\end{array}$ \\
\hline
\end{tabular}

Note: $\mathrm{F}=$ Fisher test; $P=$ probability. Letters a,b,c mean significant differences at $P<0.05$. Normality and homoscedasticity of residuals were previously tested. 
Table 2. Relative frequency of plant species $( \pm \mathrm{SD})$ in the diet of Lama guanicoe during spring (SP), summer (SU), autumn (AU), winter (WI). Origin: native (N) or exotic (E) species. Life form: tree seedlings and saplings (T), shrubs (S), erect herbs (EH), prostrate herbs $(\mathrm{PH})$, caespitose grasses $(\mathrm{CG})$, rhizomatous grasses $(\mathrm{RG})$.

Frecuencia relativa de las especies vegetales ( $\pm \mathrm{DE}$ ) presentes en la dieta de Lama guanicoe durante la primavera (SP), verano (SU), otoño (UA), invierno (WI). Origen: especies nativas (N) o exóticas (E). Formas de vida: plántulas de Nothofagus spp. (T), arbustos (S), hierbas erectas (EH), hierbas postradas $(\mathrm{PH})$, pastos cespitosos $(\mathrm{CG})$ y pastos rizomatosos $(\mathrm{RG})$.

\begin{tabular}{|c|c|c|c|c|c|c|}
\hline Species & Life form & Origin & SP & SU & $\mathrm{AU}$ & WI \\
\hline Acaena spp. & EH-PH & $\mathrm{N}$ & $1.1(0.6)$ & - & $1.4(0.9)$ & $3.3(1.6)$ \\
\hline Agrostis spp. & RG-CG & $\mathrm{N}$ & $6.1(2.4)$ & $5.6(2.0)$ & $3.9(2.3)$ & $7.1(2.8)$ \\
\hline Alopecurus magellanicus & CG & $\mathrm{N}$ & $3.1(0.6)$ & $4.4(2.5)$ & - & $3.9(1.8)$ \\
\hline Arjona spp. & $\mathrm{EH}$ & $\mathrm{N}$ & - & $0.3(0.3)$ & - & - \\
\hline Berberis buxifolia & S & $\mathrm{N}$ & $2.5(0.7)$ & $0.6(0.4)$ & $6.6(1.4)$ & $2.0(0.8)$ \\
\hline Blechnum penna marina & $\mathrm{EH}$ & $\mathrm{N}$ & $0.3(0.1)$ & $0.7(0.3)$ & - & $2.3(1.2)$ \\
\hline Bromus unioloides & $\mathrm{CG}$ & $\mathrm{N}$ & - & - & $0.3(0.3)$ & - \\
\hline Calceolaria biflora & $\mathrm{EH}$ & $\mathrm{N}$ & - & $0.3(0.3)$ & - & - \\
\hline Carex spp. & RG & $\mathrm{N}$ & $23.2(0.8)$ & $14.2(3.6)$ & $15.4(2.0)$ & 16.0 \\
\hline Cerastium spp. & $\mathrm{PH}$ & E-N & $0.8(0.5)$ & $2.0(1.1)$ & $4.2(2.1)$ & $1.7(0.7)$ \\
\hline Cotula scariosa & $\mathrm{PH}$ & $\mathrm{N}$ & $0.1(0.1)$ & $0.7(0.7)$ & - & $1.5(1.0)$ \\
\hline Deschampsia spp. & CG-RG & $\mathrm{N}$ & $8.7(1.9)$ & $5.4(1.1)$ & $7.4(0.3)$ & $13.4(2.2)$ \\
\hline Empetrum rubrum & $S$ & $\mathrm{~N}$ & $2.3(0.8)$ & $2.8(1.6)$ & $0.1(0.1)$ & $5.0(0.9)$ \\
\hline Epilobium australe & $\mathrm{EH}$ & $\mathrm{N}$ & $0.7(0.7)$ & $0.3(0.3)$ & $0.3(0.3)$ & $0.2(0.1)$ \\
\hline Erigeron myosotis & $\mathrm{EH}$ & $\mathrm{N}$ & $0.6(0.3)$ & - & - & - \\
\hline Erodium cicutarium & $\mathrm{PH}$ & $\mathrm{E}$ & - & - & $0.4(0.3)$ & - \\
\hline Festuca magellanica & CG & $\mathrm{N}$ & $1.6(0.7)$ & $3.2(1.4)$ & $2.5(1.3)$ & $5.9(0.9)$ \\
\hline Galium spp. & $\mathrm{PH}$ & E-N & $1.1(1.1)$ & $0.7(0.4)$ & $2.3(0.8)$ & $0.9(0.5)$ \\
\hline Gaultheria pumila & S & $\mathrm{N}$ & - & - & - & $2.0(1.0)$ \\
\hline Geum magellanicum & $\mathrm{EH}$ & $\mathrm{N}$ & - & $10.7(2.6)$ & - & - \\
\hline Gunnera magellanica & $\mathrm{PH}$ & $\mathrm{N}$ & $1.5(0.8)$ & $0.4(0.3)$ & - & $0.7(0.3)$ \\
\hline Hordeum sp. & $\mathrm{CG}$ & $\mathrm{N}$ & - & - & - & $1.5(1.5)$ \\
\hline Juncus scheuzerioides & RG & $\mathrm{N}$ & - & - & $1.6(0.8)$ & $7.5(2.0)$ \\
\hline Luzula alopecurus & CG & $\mathrm{N}$ & $0.1(0.1)$ & $0.6(0.3)$ & - & - \\
\hline Misodendrum spp. & S & $\mathrm{N}$ & $8.1(3.0)$ & $8.8(2.2)$ & $10.1(0.3)$ & $15.2(5.6)$ \\
\hline Nanodea muscosa & $\mathrm{PH}$ & $\mathrm{N}$ & $0.2(0.2)$ & - & - & - \\
\hline Nothofagus antarctica & $\mathrm{T}$ & $\mathrm{N}$ & - & $5.3(2.2)$ & $0.3(0.2)$ & $3.7(1.3)$ \\
\hline Nothofagus pumilio & $\mathrm{T}$ & $\mathrm{N}$ & $30.1(2.8)$ & $23.5(2.9)$ & $31.7(6.2)$ & $0.9(0.9)$ \\
\hline Osmorhiza spp. & EH & $\mathrm{N}$ & $0.5(0.2)$ & $0.6(0.6)$ & - & $0.1(0.1)$ \\
\hline Plantago barbata & $\mathrm{EH}$ & $\mathrm{N}$ & - & $0.1(0.1)$ & $10.3(5.6)$ & - \\
\hline Ranunculus spp. & EH-PH & $\mathrm{N}$ & $0.1(0.1)$ & $1.1(1.0)$ & - & - \\
\hline Rubus geoides & $\mathrm{S}$ & $\mathrm{N}$ & $5.0(1.9)$ & - & - & - \\
\hline Rumex acetosella & EH & E & $0.3(0.2)$ & - & - & - \\
\hline Senecio allophyllus & EH & $\mathrm{N}$ & - & $1.1(1.1)$ & - & $1.0(1.0)$ \\
\hline Senecio magellanicus & $\mathrm{EH}$ & $\mathrm{N}$ & $0.4(0.4)$ & $1.2(0.7)$ & $0.5(0.3)$ & $2.0(0.7)$ \\
\hline Trisetum spicatum & CG & $\mathrm{N}$ & $0.5(0.5)$ & $0.3(0.3)$ & $0.7(0.7)$ & - \\
\hline Vicia magellanica & $\mathrm{PH}$ & $\mathrm{N}$ & - & $0.7(0.4)$ & - & - \\
\hline Sphagnum sp. & Moss & $\mathrm{N}$ & $1.1(0.4)$ & $4.5(2.1)$ & - & $2.0(0.4)$ \\
\hline
\end{tabular}


According to Ivlev index, herbs groups were avoided (-0.36 for erect and -0.66 for prostrate), while tree seedlings and saplings were slightly selected (0.60) (figure 2). Consumption proportion for the grasses group ( 0.04 for caespitose and 0.08 for rhizomatous) and shrubs $(-0.01)$ equaled their availability.

Linking diet composition and vegetation type. Most plant life forms were grazed or browsed all around the year (e.g. shrubs, prostrate herbs and caespitose grasses; figure 3). Tree seedlings and saplings were browsed in all seasons, but significantly decreased during winter $(F=14.42, \mathrm{df}=3$, $P<0.001)$. Cover of these seedlings was most abundant in unmanaged $N$. pumilio forests (21.3\%) and harvested $N$. pumilio forests $(6.9 \%)$, but also appeared in open lands $(5.8 \%$ of $N$. antarctica; table 1). Erect herbs were more grazed in summer, but feeding decreased to a minimum during spring, and was mainly found in harvested $N$. pumilio forests and $N$. antarctica forests. The rhizomatous grasses were more grazed during winter, and lower feeding on this group occurred during summer. These grasses were mainly found in open lands. Finally, the Sphagnum sp. present in peat bogs was consumed throughout the year (except in autumn), as well as the hemiparasitic Misodendrum spp. which was also relatively constant between seasons, but it tended to increase during winter (non-statistically significant).

When the relationship between plant species found in feces (table 2) and vegetation census (Appendices 1 to 3) was analyzed, it was possible to observe a feeding preference defined as a ratio between cover at landscape level and occurrence in feces (figure 4). For example, species of Agrostis, Deschampsia, Carex or Nothofagus were plants

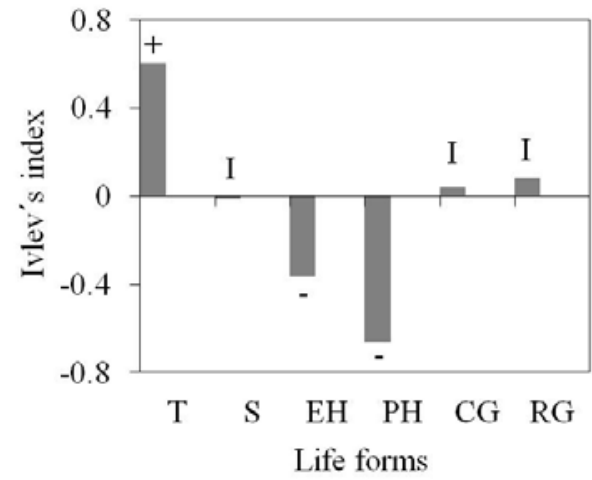

Figure 2. Ivlev's selectivity index for plant life forms: tree seedlings and saplings $(\mathrm{T})$, shrubs $(\mathrm{S})$, erect herbs $(\mathrm{EH})$, prostrate herbs $(\mathrm{PH})$, caespitose grasses $(\mathrm{CG})$, rhizomatous grasses $(\mathrm{RG})$. $+=$ selection; $-=$ avoidance; $\mathrm{I}=$ indifference. The index was calculated based on the plant availability during the summer.

Índice de selectividad de Ivlev para las diferentes formas de vida vegetal: plántulas de Nothofagus spp. (T), arbustos (S), hierbas erectas $(\mathrm{EH})$, hierbas postradas $(\mathrm{PH})$, pastos cespitosos (CG) y pastos rizomatosos (RG). + = Selección; - = evitación; I = indiferencia. El índice fue calculado en base a la disponibilidad de plantas durante el verano.

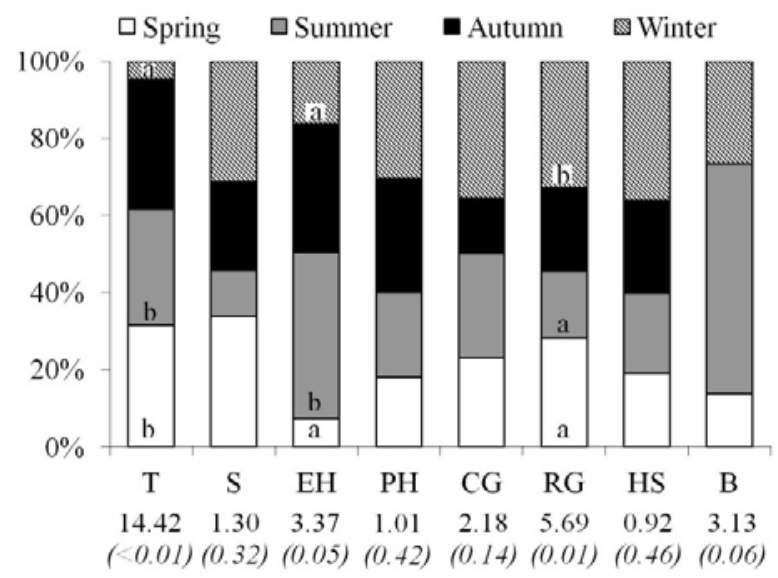

Figure 3. Seasonal foraging of different plant life forms by Lama guanicoe: tree seedlings and saplings (T), shrubs (S), erect herbs $(\mathrm{EH})$, prostrate herbs $(\mathrm{PH})$, caespitose grasses $(\mathrm{CG})$, rhizomatous grasses (RG), hemiparasitic shrubs (HS), bryophytes (B). Values below the $\mathrm{X}$-axis represent Fisher test $(\mathrm{F})$ and the probability $(P)$. Letters $\mathrm{a}, \mathrm{ab}$, and $\mathrm{b}$ on the bars showed differences by Tukey test at $P=0.05$.

Consumo estacional por parte de Lama guanicoe, de las diferentes formas de vida de plantas: plántulas de Nothofagus spp. $(\mathrm{T})$, arbustos $(\mathrm{S})$, hierbas erectas $(\mathrm{EH})$, hierbas postradas $(\mathrm{PH})$, pastos cespitosos (CG), pastos rizomatosos (RG), arbustos hemiparásitos (HS) y briófitas (B). Los valores al pie del eje $\mathrm{X}$ indican el $\mathrm{F}(P)$ de la prueba de Fisher. Letras en las barras indican diferencias por la prueba de Tukey $P=0,05$.

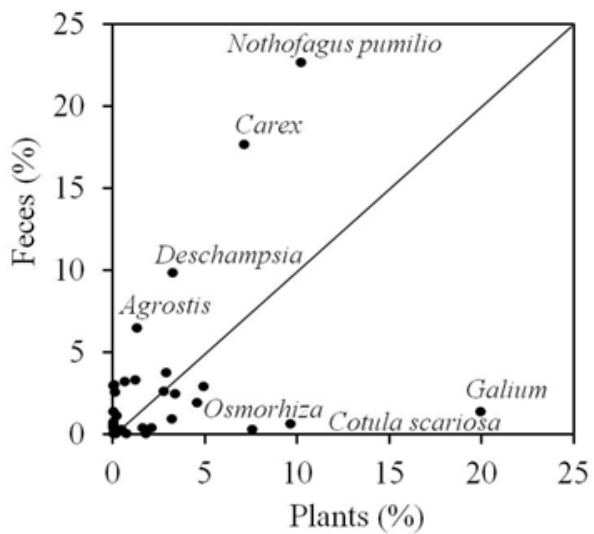

Figure 4. Relationship between plant species found in Lama guanicoe feces and their average cover at landscape level. Species or genera above the line are preferred for feeding, and below are avoided. Only the most relevant species or genera are named. Relación entre las especies vegetales encontradas en las heces Lama guanicoe y su cobertura promedio a nivel de paisaje. Las especies o géneros por encima de la línea son preferidas para la alimentación y las de abajo son evitadas. Sólo se mencionan las especies o géneros más relevantes.

highly consumed regardless of their cover at the landscape level, while other species, C. scariosa, Galium spp. or Osmorhiza spp., were avoided and occasionally consumed along the year. 


\section{DISCUSSION}

Plant species composition across the landscape. Plant diversity greatly changed at the landscape level, but most of them (in our study, 59 species) are shared between at least two different habitats. Open lands presented more exclusive species ( 40 species) than the ones presented by the other environments. Many plant species found in grassland and peatlands are adapted to extreme conditions such as strong wind, long periods of drought and radiation, and evapotranspiration. Collantes et al. (1999) described the abundance of $E$. rubrum and other cushion shrubs associated with acidic, poor nutrient soils, or the dominance of sclerophyllous tussock grasses (e.g., Festuca spp., Carex spp.) along xeric steppes. However, on moister grasslands of Tierra del Fuego, the most important factor affecting longterm productivity is possibly the occurrence of life-form shifts in the plant communities, which could be attributed to grazing disturbance (Collantes et al. 1999) replacing palatable grasses by unpalatable species for native wildlife.

Nothofagus spp. forests supported a relatively low richness of understory plant species, and all of them could be found in other habitats. However, unmanaged N. pumilio forests offer the greatest proportion of tender seedlings and saplings, palatable for the herbivores, while the presence of shrubs and grasses are poor. We observe that in harvested forests, the diversity and cover of understory plant species (e.g. grasses and herbs) absent from the original condition increased, becoming more similar to other communities. The environmental changes due to forest harvesting also allow the establishment of alien species (Martínez Pastur et al. 2002). Many of these plants have adapted to environmental conditions of southern Patagonia, extending their distribution in different habitat types of Tierra del Fuego (Moore 1983), including several palatable grasses (e.g. Hordeum comosum or Poa pratensis) that also appear in the diet of native herbivores. It could reflect the successful adaptation of both exotic plants and the herbivores feeding on them.

Seasonal diet composition and main feeding sites. The food habits of guanacos in central Tierra del Fuego were characterized by: (1) the dominance of grasses (particularly Carex spp.) and tree seedlings and saplings (Nothofagus spp.); (2) the small contribution of herbs groups (Dicotyledons); (3) clear seasonal variations; and (4) intermediate values of selectivity which could indicate an intermediate feeder (Baldi et al. 2004). Similar botanical composition of the diet has been described by previous authors for guanaco populations in South Patagonia Argentina (Bonino and Pelliza Sbriller 1991), where grasses and tree leaves represented together almost half of the total bulk of the diet. Although Bonino and Pelliza Sbriller (1991) and Baldi et al. (2004) described a wide variety of plant species in the guanaco diet, in our study some groups of plants were proportionally less consumed than their availability (as it was measured during summer). However, it is not possible to describe a preference-avoidance pattern for guanacos in Tierra del Fuego, since this would require evaluating forage availability during all studied seasons. Certain selectivity patterns have been previously described for the guanaco diet (Puig et al. 1997) and other camelids in continental desert habitats (Vicugna vicugna, vicuña; Borgina et al. 2010). Also, other factors that determine the herbivores diet are the biomass and quality (crude protein and digestibility) of forage (Baldi et al. 2004). For better understanding, in future studies our results should be complemented with these variables.

The proportion of the different plant functional types consumed greatly changed along seasons. Despite the continued use of caespitose grasses, guanacos increased the percentage of rhizomatous grasses and shrubs, and decreased the percentage of trees and erect herbs in their diet from spring to winter. While the consumption of deciduous trees decreases in winter, the feeding of shrubs increases due to the high abundance of evergreen species such as E. rubrum. Our results agree with previous work on the guanaco diet in other parts of their range. For example, in the arid and semi-arid Patagonian steppe of Chubut Province (Argentina), guanacos changed their diet from mainly Monocotyledons plants in spring to Dicotyledons plants (woody and herbaceous combined) in summer, when annual grasses are less available (Baldi et al. 2004). Seasonal changes of dietary composition also occur in domestic herbivores such as sheep or cattle (Baldi et al. 2004, Soler et al. 2012). Even the dietary similarities between sympatric guanacos and sheep in Patagonia generate a potential condition for interspecific competition, mainly during those seasons when forage is scarce (Baldi et al. 2004). In response to this competition, mainly involving sheep, seasonal displacements steppe-to-forest of guanaco populations have been described for Tierra del Fuego (Raedeke 1978, Cavieres and Fajardo 2005). Thus, guanacos would make use of the forest as a feeding place but also as a refuge or sleeping area (Montes et al. 2000). Beside this, during summer guanacos also use high elevation grasses and tree-line forests (Raedeke 1978). More studies of guanacos related to competition with domestic herbivores, habitat use and impact over selective behavior feeding must be conducted to bring new tools to promote integrated management of ecosystems and conservation planning at landscape level for the species.

This study also reports the use of Sphagnum spp. and Misodendrum spp. as food source. The moss could be incidentally consumed in bogs where Carex spp. cover is abundant. In the second case, Misodendrum spp. is a hemiparasitic and evergreen shrub that could be eaten with the branches of its host (Nothofagus spp. trees) mainly in winter. Because the snow accumulation in winter (1-1.5 m, even into the forest) almost completely cover seedlings and saplings $(<1.3 \mathrm{~m}$ high) at the forest floor (in harvested or unmanaged stands), we suggest that guanacos could brow- 
se on low-height mature trees or secondary stands with accessible branches for guanacos (e.g. N. antarctica forests). Also considering the ground level increase. This may be a possible explanation why tree consumption decreases but the frequency of Misodendrum spp. increases in the winter diet. Ortega and Franklin (1987) affirm that trees were rarely used by guanacos during winter in Torres del Paine National Park (Chile), while Bonino and Pelliza Sbriller (1991) detected similar proportion of tree consumption through the year in Tierra del Fuego (Argentina). According to our results, grasslands and Nothofagus spp. primary forests would be the most common feeding sites for guanacos in Tierra del Fuego. However, this pattern is not uniform throughout the year. Nothofagus spp. forests appear to be the main source of food for guanacos during summer and spring, depending more on open areas during the winter season.

Implications for forest management. Increasing demands for forest supplies and energy will continue to set up pressures on valuable forest systems. Measures to achieve this include attaining larger shares of natural regeneration and tree retention (e.g. Martínez Pastur et al. 2009) in order to incorporate elements of natural forest structures and dynamics in managed forests. These actions will have both direct and indirect consequences for the ungulates. For example, food resources at the stand scale are likely to be affected immediately (Edenius et al. 2002). Because the guanaco is an endemic component inhabiting Tierra del Fuego for more than 8,000 years, we consider that historically they have not been an impediment for the regeneration of Nothofagus spp. forests. Even the natural regeneration cycle, which has evolved with guanaco browsing, is 300-500 years (Muñoz 2008). The effect of native ungulates as a limiting factor on early growth of Nothofagus spp. regeneration has been reported by several authors (Pulido et al. 2000, Muñoz 2008). But there has been no quantitative evaluation of the impact of browsing on the stems growth-form and productive consequences.

The apparent forestry problem appears with silvicultural practices, where seedlings are thicker and higher than in primary forests and other palatable exotic species increase in number and biomass (Martinez Pastur et al. 2002, Soler et al. 2012). Many areas are being subjected to multiple threats simultaneously, and the interactions among them could lead to serious problems. For example, in southern Chile, Echeverría et al. (2007) documented positive feedback between the effects of habitat fragmentation, intensity of browsing by livestock and harvesting of trees for timber. As forest patches decline in area, they become more accessible to both people and livestock, progressively eliminating old-growth forest areas from the landscape (Luque et al. 2011). Conducting studies about the real use of $N$. pumilio harvested stands by guanacos and quality of food in different habitats types must be essential before formal recommendations. For the moment, the results reported in this paper should be considered in the planning of productive activities related to Nothofagus spp. forests-grasses mosaic.

\section{ACKNOWLEDGEMENTS}

We are grateful to Julio Escobar, Ricardo Vukasovic and Boris Díaz, who helped in the samples collection. We also thank Christopher B. Anderson for the comments to the manuscript.

\section{REFERENCES}

Baldi R, A Pelliza-Sbriller, D Elston, S Albon. 2004. High potential for competition between guanacos and sheep in Patagonia. Journal of Wildlife Management 68(4): 924-938.

Bonino N, A Pelliza Sbriller. 1991. Composición botánica de la dieta del guanaco (Lama guanicoe) en dos ambientes contrastantes de Tierra del Fuego, Argentina. Ecología Austral 1: 97-102.

Borgina M, VL Vilá, MH Cassini. 2010. Foraging ecology of Vicuña, Vicugna vicugna, in dry Puna of Argentina. Small Ruminant Research 88: 44-53.

Cavieres LA, A Fajardo. 2005. Browsing by guanaco (Lama guanicoe) on Nothofagus pumilio forest gaps in Tierra del Fuego, Chile. Forest Ecology and Management 204: 237-248.

Collantes MB, J Anchorena, AM Cingolani. 1999. The steppes of Tierra del Fuego: floristic and growth-form patterns controlled by soil fertility and moisture. Plant Ecology 140 : 61-75.

Echeverría C, AC Newton, A Lara, JM Rey Benayas, DA Coomes. 2007. Impacts of forest fragmentation on species composition and forest structure in the temperate landscape of southern Chile. Global Ecology and Biogeography 16: 426-439.

Edenius L, M Bergman, G Ericsson, K Danell. 2002. The role of moose as a disturbance factor in managed boreal forests. Silva Fennica 36: 57-67.

Krebs CJ. 1989. Ecological Methodology. Nueva York, USA. Harper \& Row Publishers. 654 p.

Lencinas MV, G Martínez Pastur, P Rivero, C Busso. 2008. Conservation value of timber quality vs. associated non-timber quality stands for understory diversity in Nothofagus forests. Biodiversity and Conservation 17: 2579-2597.

Luque S, G Martínez Pastur, C Echeverría, MJ Pacha. 2011. Overview of biodiversity loss in South America: a landscape perspective for sustainable forest management and conservation in temperate forests. In Li C, R Lafortezza, J Chen eds. Landscape Ecology in Forest Management and Conservation. Beijing, China. Springer. p. 352-379.

Martínez Pastur G, PL Peri, C Fernández, G Staffieri, MV Lencinas. 2002. Changes in understory species diversity during the Nothofagus pumilio forest management cycle. Journal of Forest Research 7: 165-174.

Martínez Pastur G, MV Lencinas, JM Cellini, PL Peri, RM Soler. 2009. Timber management with variable retention in Nothofagus pumilio forests of Southern Patagonia. Forest Ecology and Management 258: 436-443.

Mittermeier R, C Mittermeier, P Robles-Gil, J Pilgrim, G Fonseca, J Brooks, J Konstant. 2003. Wilderness: Earth's last wild places. Washington, USA. Conservation International. 575 p. 
Moore D. 1983. Flora of Tierra del Fuego. England, United Kingdom. Anthony Nelson. 396 p.

Muñoz AE. 2008. Guanaco (Lama guanicoe) browsing on lenga (Nothofagus pumilio) regeneration in Tierra del Fuego. Master Thesis in Biological Science. Santiago, Chile. Chile University. 37 p.

Montes C, DA De Lamo, J Zavatti. 2000. Distribución de abundancias de guanacos (Lama guanicoe) en los distintos ambientes de Tierra del Fuego, Argentina. Journal of Neotropical Mammalogy 7: 23-31.

Ormaechea S, PL Peri, R. Molina, JP Mayo. 2009. Situación y manejo actual del sector ganadero en establecimientos con bosque de ñire (Nothofagus antarctica) de Patagonia sur. In Peri PL ed. Actas $1^{\circ}$ Congreso Nacional de Sistemas Silvopastoriles. Misiones, Argentina. INTA. p. 385-393.

Pauchard A, E Ugarte, J Millán. 2000. A Multiscale method for assessing vegetation baseline of environmental impact assessment (EIA) in protected areas of Chile. USDA Forest Service Proceedings 15: 111-116.

Puig S, F Videla, MI Cona. 1997. Diet and abundance of the guanaco (Lama guanicoe Müller 1776) in four habitats of northern Patagonia, Argentina. Journal of Arid Environments
36: 343-357.

Pulido F, B Díaz, G Martínez Pastur. 2000. Incidencia del ramoneo del guanaco (Lama guanicoe) sobre la regeneración de lenga (Nothofagus pumilio) en bosques de Tierra del Fuego, Argentina. Investigación Agraria: Sistemas y Recursos Forestales 9: 381-394.

Raedeke KJ. 1978. El guanaco en Magallanes, Chile: su distribución y biología. Santiago, Chile. CONAF. 222 p.

Ragonese AM. 1981. Leaf anatomy of South American species of Nothofagus Bl. (Fagaceae). Darwiniana 23: 587-603.

Sepúlveda L, A Pelliza Sbriller, M Manacorda. 2004. Importancia de los tejidos no epidérmicos en el análisis de la dieta de herbívoros. Ecología Austral 14: 31-38.

Somlo R, G Bonvisutto, T Schlichter, P Laclau, PL Peri, M Allogia. 1997. Silvopastoral use of Argentine Patagonian Forests. In Gordon AM, SM Newman eds. Temperate agroforestry systems. England, United Kingdom. CAB Internacional. p. 237-250.

Soler RM, G Martínez Pastur, MV Lencinas, L Borrelli. 2012. Differential forage use between large native and domestic herbivores in Southern Patagonian Nothofagus forests. Agroforesty Systems 85(3): 397-409. 
Appendix 1. Percent coverage $( \pm \mathrm{SD})$ of dicotyledons plants obtained from vegetation surveys in open lands (OL), Nothofagus antarctica forests (Ñ), primary unmanaged $N$. pumilio forests (PF), harvested N. pumilio forests (HF). Life form: tree seedlings and saplings $(\mathrm{T})$, shrubs (S), erect herbs $(\mathrm{EH})$, prostrate herbs $(\mathrm{PH})$.

Porcentaje de cobertura $( \pm \mathrm{DE})$ de plantas dicotiledóneas, a partir de los censos de vegetación en áreas abiertas $(\mathrm{OL})$, bosques de Nothofagus antarctica $(\mathrm{N})$, bosques primarios de $N$. pumilio (PF) y bosques cosechados de N. pumilio (HF). Formas de vida: plántulas de Nothofagus spp. (T), arbustos (S), hierbas erectas (EH) y hierbas postradas $(\mathrm{PH})$.

\begin{tabular}{|c|c|c|c|c|c|c|}
\hline \multirow{2}{*}{ Species } & \multirow{2}{*}{$\begin{array}{l}\text { Life } \\
\text { form }\end{array}$} & \multirow{2}{*}{ Feces } & \multicolumn{4}{|c|}{ Habitat } \\
\hline & & & OL & $\tilde{\mathrm{N}}$ & $\mathrm{PF}$ & $\mathrm{HF}$ \\
\hline Acaena magellanica (Lam.) Vah & $\mathrm{PH}$ & G & $1.6(0.5)$ & $0.9(0.3)$ & $0.8(0.5)$ & $1.4(0.2)$ \\
\hline Acaena ovalifolia Ruiz et Pavón & $\mathrm{PH}$ & G & $0.8(0.4)$ & $1.8(0.4)$ & $0.8(0.3)$ & $5.7(0.7)$ \\
\hline Acaena pinnatifida Ruiz et Pavón & $\mathrm{EH}$ & G & $0.1(<0.1)$ & $<0.1(<0.1)$ & - & $<0.1(<0.1)$ \\
\hline Achillea millefolium L. & $\mathrm{EH}$ & $\mathrm{N}$ & $1.0(0.9)$ & $0.4(0.2)$ & - & $0.2(0.1)$ \\
\hline Adenocaulon chilense Less. & $\mathrm{EH}$ & $\mathrm{N}$ & - & - & - & $0.1(<0.1)$ \\
\hline Agoseris coronopifolium (D’Urv.) Chambers ex D.M. Moore & $\mathrm{EH}$ & $\mathrm{N}$ & $<0.1(<0.1)$ & - & - & $<0.1(<0.1)$ \\
\hline Arenaria serpens Humb., Bonpl. et Kunth & $\mathrm{PH}$ & $\mathrm{N}$ & $0.1(<0.1)$ & - & - & - \\
\hline Azorella lycopodioides Gaudich. & S & $\mathrm{N}$ & $1.6(1.2)$ & - & - & - \\
\hline Azorella trifurcata (Gaertner) Hooker f. & S & $\mathrm{N}$ & $0.7(0.4)$ & - & - & $<0.1(<0.1)$ \\
\hline Berberis buxifolia Lam. & S & G & $1.8(1.0)$ & $1.3(0.3)$ & $<0.1(<0.1)$ & $0.1(<0.1)$ \\
\hline Berberis empetrifolia Lam. & $\mathrm{S}$ & G & $0.1(<0.1)$ & - & - & - \\
\hline Bolax gummifera (Lam.) Sprengel & S & $\mathrm{N}$ & $2.1(1.2)$ & - & - & - \\
\hline Calceolaria biflora Lam. & $\mathrm{EH}$ & $\mathrm{S}$ & $<0.1(<0.1)$ & $0.1(<0.1)$ & - & $<0.1(<0.1)$ \\
\hline Caltha sagitata Cav. & $\mathrm{PH}$ & $\mathrm{N}$ & $3.4(1.2)$ & - & - & - \\
\hline Capsella bursa pastoris L. Medicus & $\mathrm{EH}$ & $\mathrm{N}$ & - & $0.1(0.1)$ & - & $0.2(0.1)$ \\
\hline Cardamine glacialis (Forster f.) DC. & $\mathrm{EH}$ & $\mathrm{N}$ & - & $0.4(0.1)$ & $1.7(0.5)$ & $1.8(0.3)$ \\
\hline Cerastium arvense L. & $\mathrm{PH}$ & G & $0.4(0.2)$ & $0.4(0.1)$ & $0.2(0.2)$ & $1.1(0.4)$ \\
\hline Cerastium fontanum Baumg. & $\mathrm{PH}$ & $\mathrm{G}$ & $0.1(<0.1)$ & $0.7(0.2)$ & $0.7(0.3)$ & $5.7(0.7)$ \\
\hline Chiliotrichum diffusum (Forster f.) O. Kuntze & S & $\mathrm{N}$ & $0.1(<0.1)$ & - & - & - \\
\hline Cirsium vulgare (Savi) Ten. & $\mathrm{EH}$ & $\mathrm{N}$ & - & - & - & $0.2(0.1)$ \\
\hline Colobanthus quitensis (Kunth) Bartl. & $\mathrm{PH}$ & $\mathrm{N}$ & $0.2(0.1)$ & - & - & - \\
\hline Coronopus dydimus (L.) Sm. & $\mathrm{PH}$ & $\mathrm{N}$ & $<0.1(<0.1)$ & - & - & - \\
\hline Cotula scariosa (Cass.) Franchet & $\mathrm{PH}$ & $\mathrm{S}$ & $0.6(0.2)$ & $22.1(2.0)$ & $9.0(3.0)$ & $3.0(0.6)$ \\
\hline Draba magellanica Lam. & $\mathrm{EH}$ & $\mathrm{N}$ & - & $<0.1(<0.1)$ & - & - \\
\hline Dysopsis glechomoides (A. Richard) Müller Arg. & $\mathrm{PH}$ & $\mathrm{N}$ & - & $0.2(0.1)$ & $1.0(0.6)$ & $6.5(1.2)$ \\
\hline Empetrum rubrum Vahl exWilld. & S & $\mathrm{S}$ & $14.1(4.5)$ & - & - & - \\
\hline Epilobium austral Poeppig et Hausskn. & $\mathrm{EH}$ & $\mathrm{S}$ & - & - & - & $<0.1(<0.1)$ \\
\hline Erigeron myosotis Pers. & $\mathrm{EH}$ & $\mathrm{S}$ & $0.3(0.2)$ & - & - & - \\
\hline Euphrasia antarctica Bentham & $\mathrm{EH}$ & $\mathrm{N}$ & $0.1(<0.1)$ & - & - & - \\
\hline Galium antarcticum Hooker f. & $\mathrm{PH}$ & G & - & $0.5(0.2)$ & - & - \\
\hline Galium aparine L. & $\mathrm{PH}$ & G & - & $8.9(1.4)$ & $33.8(1.4)$ & $16.1(3.8)$ \\
\hline Galium fuegianum Hooker f. & $\mathrm{PH}$ & G & - & $0.5(0.1)$ & - & $0.5(0.1)$ \\
\hline Gaultheria pumila (L. f.) Middleton & S & $\mathrm{S}$ & $<0.1(<0.1)$ & $<0.1(<0.1)$ & - & - \\
\hline Gamochaeta spiciformis (sch. Bip.) Cabrera & $\mathrm{EH}$ & $\mathrm{N}$ & $0.1(<0.1)$ & $<0.1(<0.1)$ & - & $<0.1(<0.1)$ \\
\hline Gentiana postata Haenke & $\mathrm{EH}$ & $\mathrm{N}$ & $0.1(<0.1)$ & - & - & - \\
\hline Gentianella magellanica (Gaud.) Fabris ex D.M.Moore & $\mathrm{PH}$ & $\mathrm{N}$ & $0.3(0.1)$ & $<0.1(<0.1)$ & $<0.1(<0.1)$ & $0.1(<0.1)$ \\
\hline Geum magellanicum Comm. Ex Pers. & $\mathrm{EH}$ & $\mathrm{S}$ & $0.2(<0.1)$ & $<0.1(<0.1)$ & - & - \\
\hline Gunnera magellanica Lam. & $\mathrm{PH}$ & $\mathrm{S}$ & $0.1(<0.1)$ & - & - & - \\
\hline Hieracium antarcticum D'Urv. & $\mathrm{EH}$ & $\mathrm{N}$ & - & $<0.1(<0.1)$ & - & - \\
\hline
\end{tabular}


Appendix 1 continued

\begin{tabular}{|c|c|c|c|c|c|c|}
\hline Leucanthemum vulgare Lam. & $\mathrm{EH}$ & $\mathrm{N}$ & $0.5(0.4)$ & $<0.1(<0.1)$ & - & $0.2(0.1)$ \\
\hline Nanodea muscosa Banks. ex C.F. Gaertner & $\mathrm{PH}$ & $\mathrm{S}$ & $0.4(0.2)$ & - & - & - \\
\hline Nothofagus antarctica (Forster f.) Oersted & $\mathrm{T}$ & $\mathrm{S}$ & $5.8(2.2)$ & $1.4(0.3)$ & $0.2(0.1)$ & $0.2(0.1)$ \\
\hline Nothofagus pumilio (Poepp. et Endl.) Krasser & $\mathrm{T}$ & $\mathrm{S}$ & - & $0.1(<0.1)$ & $21.2(2.4)$ & $6.7(0.8)$ \\
\hline Osmorhiza chilensis Hooker et Arn. & $\mathrm{EH}$ & G & - & $0.4(0.1)$ & - & $<0.1(<0.1)$ \\
\hline Osmorhiza depauperata Phil. & $\mathrm{EH}$ & $\mathrm{G}$ & $<0.1(<0.1)$ & $8.3(1.6)$ & $10.1(1.1)$ & $13.0(0.9)$ \\
\hline Oxalis magellanica Forster $\mathrm{f}$. & $\mathrm{PH}$ & $\mathrm{N}$ & $<0.1(<0.1)$ & - & - & - \\
\hline Plantago barbata Forster f. & $\mathrm{EH}$ & $\mathrm{S}$ & $<0.1(<0.1)$ & - & - & - \\
\hline Polygonum aviculare $\mathrm{L}$. & $\mathrm{EH}$ & $\mathrm{N}$ & $<0.1(<0.1)$ & - & - & - \\
\hline Pratia longiflora Hooker $\mathrm{f}$. & $\mathrm{EH}$ & $\mathrm{N}$ & $<0.1(<0.1)$ & - & - & - \\
\hline Pratia repens Gaudich. & $\mathrm{EH}$ & $\mathrm{N}$ & $0.1(0.1)$ & - & - & - \\
\hline Primula magellanica Lhem. & $\mathrm{EH}$ & $\mathrm{N}$ & $<0.1(<0.1)$ & - & - & - \\
\hline Ranunculus biternatus Sm. & $\mathrm{PH}$ & G & - & $0.1(<0.1)$ & $<0.1(<0.1)$ & $1.0(0.5)$ \\
\hline Ranunculus fuegianus Speg. & $\mathrm{PH}$ & G & $<0.1(<0.1)$ & - & - & - \\
\hline Ranunculus maclovianus D’Urv. & $\mathrm{EH}$ & G & - & - & - & $<0.1(<0.1)$ \\
\hline Ranunculus uniflorus Phil. Ex Reiche & $\mathrm{PH}$ & G & $0.2(0.1)$ & - & - & \\
\hline Ribes magellanicum Poiret & S & $\mathrm{N}$ & $<0.1(<0.1)$ & $0.2(0.1)$ & - & $0.3(0.1)$ \\
\hline Rubus geoides Sm. & S & $\mathrm{S}$ & - & - & - & $0.1(<0.1)$ \\
\hline Rumex acetosella L. & $\mathrm{EH}$ & $\mathrm{S}$ & $0.4(0.2)$ & $1.4(0.3)$ & $0.2(0.1)$ & $2.9(0.6)$ \\
\hline Sagina procumbens L. & $\mathrm{PH}$ & $\mathrm{N}$ & - & - & - & $0.3(0.1)$ \\
\hline Schizeilema ranunculus (D’Urv.) Domin & $\mathrm{PH}$ & $\mathrm{N}$ & $0.1(0.1)$ & $4.0(0.6)$ & - & $0.8(0.3)$ \\
\hline Senecio magellanicus Hooker et Arn. & $\mathrm{EH}$ & $\mathrm{S}$ & $0.5(0.3)$ & - & - & $<0.1(<0.1)$ \\
\hline Senecio vulgaris $\mathrm{L}$. & $\mathrm{EH}$ & $\mathrm{N}$ & - & - & - & $<0.1(<0.1)$ \\
\hline Stellaria debilis D’Urv. & $\mathrm{PH}$ & $\mathrm{N}$ & - & - & - & $<0.1(<0.1)$ \\
\hline Stellaria media (L.) Vill. & $\mathrm{PH}$ & $\mathrm{N}$ & - & $0.9(0.5)$ & $0.9(0.4)$ & $2.5(0.6)$ \\
\hline Taraxacum gillesii Hooker et Arn. & $\mathrm{EH}$ & $\mathrm{N}$ & - & $0.2(<0.1)$ & - & - \\
\hline Taraxacum officinale Weber & $\mathrm{EH}$ & $\mathrm{N}$ & $1.8(1.0)$ & $2.6(0.5)$ & $4.3(0.9)$ & $4.5(0.5)$ \\
\hline Thlaspi magellanicum Comm., ex Poiret & $\mathrm{EH}$ & $\mathrm{N}$ & $<0.1(<0.1)$ & $<0.1(<0.1)$ & - & $<0.1(<0.1)$ \\
\hline Trifolium repens $\mathrm{L}$. & $\mathrm{EH}$ & $\mathrm{N}$ & $4.9(2.5)$ & $0.3(0.1)$ & - & $0.7(0.4)$ \\
\hline Veronica serpyllifolia $\mathrm{L}$. & $\mathrm{PH}$ & $\mathrm{N}$ & $0.1(<0.1)$ & $0.2(<0.1)$ & $<0.1(<0.1)$ & $0.5(0.1)$ \\
\hline Vicia magellanica Hooker f. & $\mathrm{PH}$ & $\mathrm{S}$ & - & $0.1(0.1)$ & - & $0.1(<0.1)$ \\
\hline Viola magellanica Forster $\mathrm{f}$. & $\mathrm{PH}$ & $\mathrm{N}$ & - & $0.4(0.1)$ & $0.1(0.1)$ & $1.5(0.5)$ \\
\hline
\end{tabular}

Note: items identified in faeces at species level (S), genus level (G), or without presence $(\mathrm{N})$. 
Appendix 2. Percent coverage $( \pm \mathrm{SD})$ of Monocotyledons plants obtained from vegetation surveys in open lands (OL), Nothofagus antarctica forests $(\tilde{\mathrm{N}})$, primary unmanaged $N$. pumilio forests (PF), harvested $N$. pumilio forests (HF). Life form: caespitose grasses (CG), rhizomatous grasses (RG), erect herbs (EH).

Porcentaje de cobertura $( \pm \mathrm{DE})$ de plantas Monocotiledóneas a partir de los censos de vegetación en áreas abiertas (OL), bosques de Nothofagus antarctica $(\mathrm{N})$, bosques primarios de N. pumilio (PF) y bosques cosechados de N. pumilio (HF). Formas de vida: pastos cespitosos (CG), pastos rizomatosos $(\mathrm{RG})$ y hierbas erectas $(\mathrm{EH})$.

\begin{tabular}{|c|c|c|c|c|c|c|}
\hline \multirow{2}{*}{ Species } & \multirow{2}{*}{$\begin{array}{l}\text { Life } \\
\text { form }\end{array}$} & \multirow{2}{*}{ Feces } & \multicolumn{4}{|c|}{ Habitat } \\
\hline & & & OL & $\tilde{\mathbf{N}}$ & $\mathrm{PF}$ & $\mathrm{HF}$ \\
\hline Agropyron pubiflorum (Steudel) Parodi & RG & $\mathrm{N}$ & $<0.1(<0.1)$ & - & - & - \\
\hline Agrostis magellanica Lam. & RG & G & $0.7(0.7)$ & - & - & - \\
\hline Agrostis perennans (Walter) Tuck. & $\mathrm{CG}$ & G & $2.2(1.0)$ & $0.2(0.1)$ & - & $0.1(<0.1)$ \\
\hline Agrostis uliginosa Phil. & CG & G & - & - & - & $0.4(0.3)$ \\
\hline Alopecurus magellanicus Lam. & $\mathrm{CG}$ & S & $1.6(0.7)$ & $0.1(<0.1)$ & - & $0.1(<0.1)$ \\
\hline Alopecurus pratensis L. & $\mathrm{CG}$ & $\mathrm{N}$ & $0.1(0.1)$ & - & - & - \\
\hline Bromus unioloides Humb., Bonpl. et Kunth & $\mathrm{CG}$ & S & $0.1(<0.1)$ & $1.6(0.3)$ & - & $0.4(0.1)$ \\
\hline Calamagrostis stricta (Timm) Koeler & RG & $\mathrm{N}$ & $0.8(0.3)$ & - & - & - \\
\hline Carex capitata $\mathrm{L}$. & RG & G & $<0.1(<0.1)$ & - & - & - \\
\hline Carex curta Gooden & RG & G & $11.7(3.5)$ & - & - & - \\
\hline Carex deciduas Boott & RG & G & $2.3(1.1)$ & - & - & - \\
\hline Carex fuscula D’Urv. & RG & G & $0.3(0.1)$ & - & - & - \\
\hline Carex gayana Desv. & RG & G & $3.7(2.7)$ & - & - & - \\
\hline Carex macloviana D’Urv. & RG & G & $0.1(0.1)$ & - & - & - \\
\hline Carex magellanica Lam. & RG & G & $1.5(0.5)$ & - & - & - \\
\hline Carex sorianoi Barros & RG & G & $<0.1(<0.1)$ & - & - & - \\
\hline Carex subantarctica Speg. & RG & G & $0.4(0.4)$ & - & - & - \\
\hline Dactylis glomerata L. & $\mathrm{CG}$ & $\mathrm{N}$ & - & $0.1(0.1)$ & - & - \\
\hline Deschampsia antarctica Desv. & $\mathrm{CG}$ & G & $1.0(0.9)$ & $0.2(<0.1)$ & - & $0.2(0.1)$ \\
\hline Deschampsia flexuosa (L.) Trin. & RG & G & $4.4(2.0)$ & $2.9(0.7)$ & - & $0.2(0.1)$ \\
\hline Elymus agropyroides C. Presl & RG & $\mathrm{N}$ & $0.1(<0.1)$ & $<0.1(<0.1)$ & - & $<0.1(<0.1)$ \\
\hline Festuca gracillima Hooker f. & $\mathrm{CG}$ & $\mathrm{N}$ & $1.3(1.3)$ & - & $1.0(0.5)$ & $0.6(0.2)$ \\
\hline Festuca magellanica Lam. & $\mathrm{CG}$ & S & $0.5(0.2)$ & $5.4(0.6)$ & $1.5(0.7)$ & $0.5(0.1)$ \\
\hline Holcus lanatus L. & $\mathrm{CG}$ & $\mathrm{N}$ & - & $0.2(0.1)$ & - & - \\
\hline Hordeum comosum C. Prsel & $\mathrm{CG}$ & G & $4.0(1.6)$ & $0.1(<0.1)$ & - & $0.1(<0.1)$ \\
\hline Hordeum secalinum Schreber & $\mathrm{CG}$ & G & - & - & - & $0.2(0.1)$ \\
\hline Juncus scheuzerioides Gaudich. & RG & S & $0.3(0.2)$ & - & - & - \\
\hline Luzula alopecurus Desv. & $\mathrm{CG}$ & S & $0.2(0.1)$ & $0.1(<0.1)$ & - & $<0.1(<0.1)$ \\
\hline Phaiophleps biflora (Thunb.) R.C. Foster & $\mathrm{EH}$ & $\mathrm{N}$ & $<0.1(<0.1)$ & - & - & - \\
\hline Phleum alpinum $\mathrm{L}$. & $\mathrm{CG}$ & $\mathrm{N}$ & $4.0(1.6)$ & $2.1(0.3)$ & $0.2(0.1)$ & $1.0(0.2)$ \\
\hline Phleum pratense $\mathrm{L}$. & $\mathrm{CG}$ & $\mathrm{N}$ & $0.4(0.3)$ & - & - & - \\
\hline Роа аппиа L. & CG & G & - & $0.1(<0.1)$ & - & $0.3(0.1)$ \\
\hline Poa nemoralis L. & CG & G & - & - & - & $<0.1(<0.1)$ \\
\hline Poa pratensis L. & RG & G & $9.5(2.5)$ & $17.5(1.2)$ & $10.7(2.1)$ & $12.9(1.5)$ \\
\hline Tetroncium magellanicum Willd. & RG & $\mathrm{N}$ & $<0.1(<0.1)$ & - & - & - \\
\hline Triglochin concinna Davy & RG & $\mathrm{N}$ & $0.5(0.3)$ & $<0.1(<0.1)$ & - & - \\
\hline Triglochin palustris $\mathrm{L}$. & RG & $\mathrm{N}$ & $0.4(0.2)$ & - & - & - \\
\hline Trisetum spicatum (L.) K. Richter & CG & G & $2.7(1.0)$ & $1.6(0.3)$ & $0.5(0.2)$ & $1.0(0.3)$ \\
\hline Uncinia lechleriana Steudel & RG & $\mathrm{N}$ & - & $1.9(0.3)$ & $0.1(<0.1)$ & $1.5(0.4)$ \\
\hline
\end{tabular}

Note: items identified in faeces at species level (S), genus level (G), or without presence $(\mathrm{N})$. 
Appendix 3. Percent coverage $( \pm \mathrm{SD})$ of Ferns according to the vegetation surveys in open lands (OL), Nothofagus antarctica forests $(\tilde{\mathrm{N}})$, primary unmanaged $N$. pumilio forests $(\mathrm{PF})$, harvested $N$. pumilio forests $(\mathrm{HF})$. Life form: erect herbs $(\mathrm{EH})$, prostrate herbs $(\mathrm{PH})$.

Porcentaje de cobertura $( \pm \mathrm{DE})$ de Helechos a partir de los censos de vegetación en áreas abiertas $(\mathrm{OL})$, bosques de Nothofagus antarcti$c a(\mathrm{~N})$, bosques primarios de $N$. pumilio (PF) y bosques cosechados de N. pumilio (HF). Formas de vida: hierbas erectas (EH) y hierbas postradas $(\mathrm{PH})$.

\begin{tabular}{lcccccrr}
\hline \multirow{2}{*}{ Species } & \multirow{2}{*}{$\begin{array}{c}\text { Life } \\
\text { form }\end{array}$} & Feces & \multicolumn{4}{c}{ Habitat } \\
\cline { 5 - 7 } & & OL & N & PF & HF \\
\hline Blechnum penna marina (Poiret) Kuhn & EH & S & $0.1(<0.1)$ & $6.7(1.3)$ & - & $2.0(0.5)$ \\
Cystopteris fragilis (L.) Berhn. & EH & N & $<0.1(<0.1)$ & $0.1(<0.1)$ & $0.8(0.3)$ & $0.3(0.1)$ \\
Lycopodium magellanicum (P. Beauv.) Swartz & PH & N & $0.1(<0.1)$ & - & - & - \\
\hline
\end{tabular}

Note: items identified in faeces at species level $(\mathrm{S})$, genus level $(\mathrm{G})$, or without presence $(\mathrm{N})$. 
